Jadwiga FARBISZEWSKA-BAJER, Mirosław BĄK, Andrzej GAWDZIK*, Teresa FARBISZEWSKA

Institute of Technology, University of Opole

\title{
MICROBLAL DEGRADATION OF SULFUR FROM LIGNITE ON A LARGE LABORATORY SCALE
}

Summary. Removal of sulfur compounds from brown coal has become important due to emission problems associated with direct combustion of coal. We have carried out researches into batch extraction of sulfate sulfur from lignite by Thiobacillus bacteria. It was $78 \%$ total sulfide removed from the sample of brown coal.

\section{MIKROBIOLOGICZNE ODSIARCZANIE LIGNITU W SKALI WIELKOLABORATORYJNEJ}

Streszczenie. Podczas doświadczeń nad bioekstrakcją siarki siarczkowej z węgla brunatnego w skali laboratoryjnej, zbadano wpływ temperatury, kwasowości i składu płynu ługującego, rozdrobnienia węgla oraz rodzaju i kompozycji użytych szczepów bakteryjnych na przebieg procesu. Uzyskano $78 \%$ spadek zawartości siarki calkowitej w badanym węglu brunatnym.

\section{Introduction}

There are several reports on the methods of bacterial leaching of lean ore and waste materials to gain metals (Karavaiko G.I. et al. 1972, Dugan P.R et al. 1978, Luntgren D.G et al. 1983, Kargi F. 1984).

In these methods there were Thiobacillus bacteria strains used because these strains have both a high oxidability of ions $\mathrm{Fe}^{2+}$, sulfur and inorganic sulfur compounds and adaptation capacity to high concentration of metals.

\footnotetext{
To whom correspondence should be addressed
} 
Thiobacillus ferrooxidans has been widely used organism for pyritic sulfur in brown coal open-cut mining in Turoszów Region (Poland). Sulfur bioextraction from this type of coal is studied extensively in Pedagogical University of Opole (Gawdzik A. et al. 1990, Farbiszewska-Bajer J. et al. 1991, Farbiszewska T et al. 1992).

The results of these investigation confirm advantage of biochemical methods which used Thiobacillus bacteria strains over chemical and physical methods and open up a possibility of desulfurization on a large laboratory scale.

\section{Materials and methods}

The brown coal was obtained from Turoszów region mine. After pretreatment (neutralization of basic waste rocks) $15 \mathrm{~kg}$ of brown coal samples contained $0.45 \%$ sulfur. The average diameters of coal grains were $30 \mathrm{~mm}$. The leaching medium was composed of acidified $\left(\mathrm{H}_{2} \mathrm{SO}_{4}\right)$ distilled water $(\mathrm{pH}$ 1.5) and the ore-adapted Thiobacillus ferrooxidans strain. The liquid medium contained was about $40 \%$ (i.e. $40 \mathrm{~g}$ coal $/ 100 \mathrm{ml}$ mixture). It was operated in a stoneware column at room temperature for 40 days. Simultaneously, the control (no bacterial inoculation) system was created. After every five days $\mathrm{SO}_{4}{ }^{2-}$ and $\mathrm{Fe}$ ions concentration, $\mathrm{pH}$ of leaching medium and batch activity were controlled. Finally, we use the oxygen combustion method (Farbiszewska-Bajer J. 1991) to make qualitative determination of total sulfur content in leaching brown coal.

\section{Results and discussion}

An amount of sulfur which was removed from brown coal was evaluated by checking up $\mathrm{SO}_{4}{ }^{2-}$ and $\mathrm{Fe}$ ions concentration. The contents of $\mathrm{Fe}$ ions in the culture medium are shown in Figure 1. The shape of the curves shows that after 40 days of the process $21.15 \mathrm{~g}$ of iron was leached.

By assuming that there was only sulfide iron bounded, it was equivalent to removal $24.2 \mathrm{~g}$ of sulfur (i.e. $0.16 \%$ the initial mass of coal sample). No change of these ions concentration was observed in the control medium (see Figure 2). The amount of leaching sulfur evaluated by qualitative determination of $\mathrm{Fe}$ ions was lower then the amount of sulfur 
obtained in the same way by determination $\mathrm{SO}_{4}{ }^{2-}$. This result indicates a strong adsorption of iron compounds into micropores of coal grains, bioextaction of metals sulfide from waste rocks and removing part of organic sulfur process. The efficiency of the process, connected with the activity of the bacteria culture, raised between 10-th and 30-th day (see Figure 3).

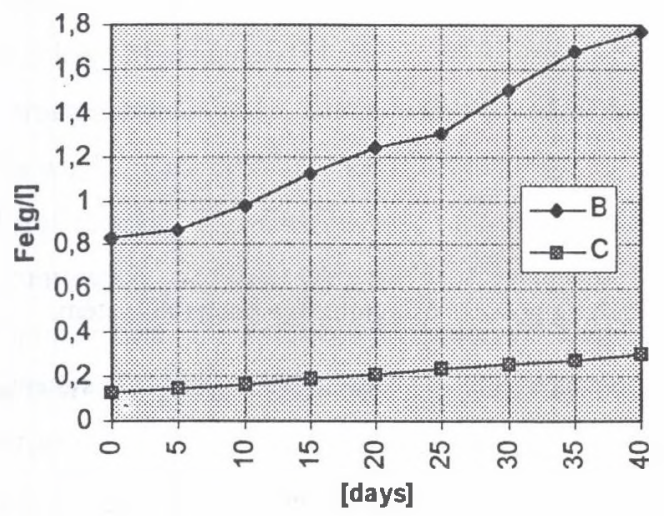

Fig. 1. Contents of $\mathrm{Fe}^{2+}$ ions in the liquid medium. B - bacterial system, $\mathrm{C}$ - control system Rys. 1. Zawartość $\mathrm{Fe}^{2+}$ jonów w cieczy: B - system bakteryjny, C - system kontrolny

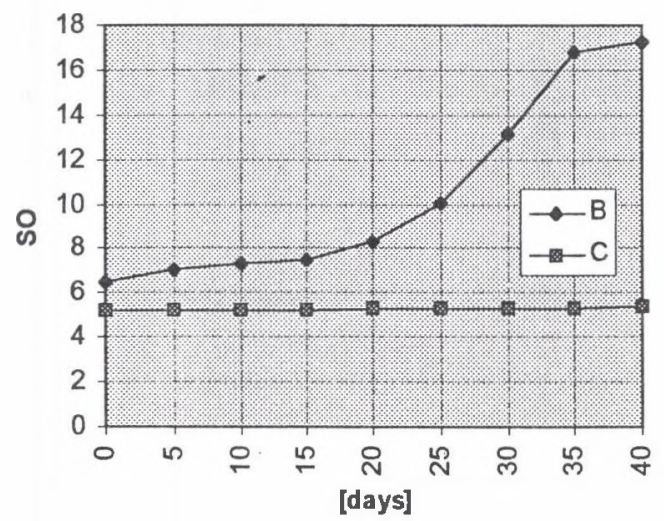

Fig. 2. Contents of $\mathrm{SO}_{4}{ }^{2 \cdot}$ in liquid medium, B - bacterial system, C - control system Rys.2. Zawartość $\mathrm{SO}_{4}{ }^{2-}$ jonów w cieczy: $\mathrm{B}$ - system bakteryjny, C - system kontrolny 


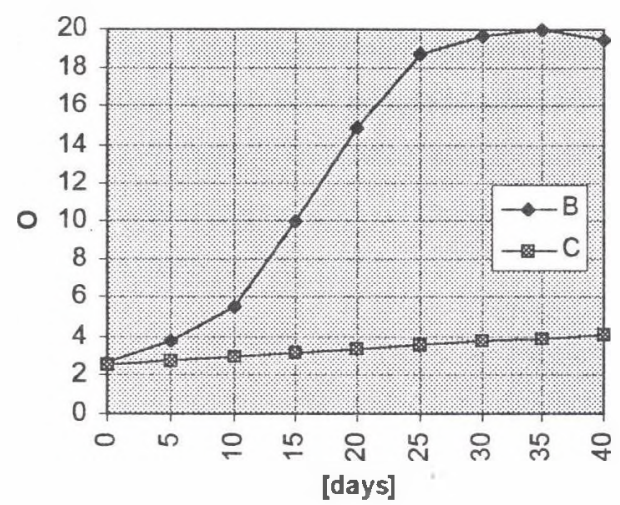

Fig. 3. Biological bacteria activity in the leaching process of lignite, B - bacterial system, C - control system

Rys.3. Aktywność bakterii w procesie hugowania lignitu: B - system bakteryjny, C - system kontrolny

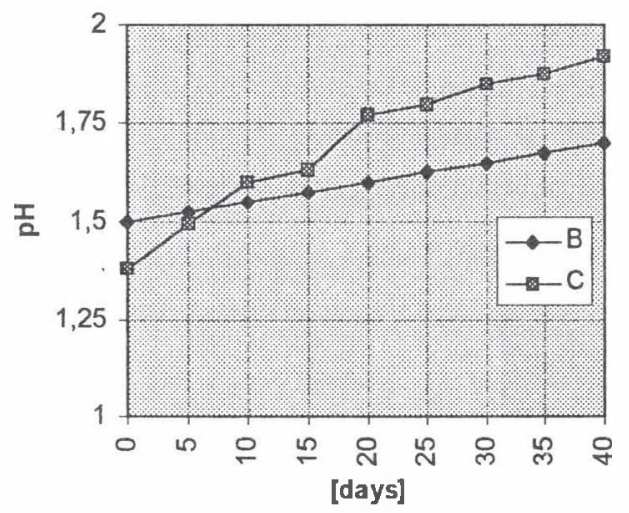

Fig. 4. Changes of acidity during the batch leaching process, B - bacterial system, C - control system

Rys.4. Zmiany kwasowości podczas lugowania próbek: B - system bakteryjny C - system kontrolny

Similarly, lower activity of the bacteria culture after 30-th day causes the decreasing of the process. The results obtained in this investigation indicate that the bacteria culture removed $78 \%$ total sulfur from the sample of brown coal. This value was verified by coal analysis. It contains $0.11 \%$ of sulfur. From these results it is concluded that this technique has great potential to be effectively used to remove sulfur from brown coal. 


\section{REFERENCES}

1. Dugan P.R., Apel W.A., w: Murr L.E., Torma A.E., Brierley J.A. (eds): Metallurgical Applications of Bacterial Leaching and Related Microbiological Phenomena. Acad.Press, New York 1978, 223-250.

2. Farbiszewska-Bajer J., Farbiszewska T.: Bioekstrakcja siarki z węgla brunatnego. Wpływ ziarnistości węgla i temperatury na wydajność procesu, Fizykochemiczne Problemy Mineralurgii, 24, 1991, 83-93.

3. Farbiszewska-Bajer J. , Zastosowanie bakteryjnego hugowania do wstępnego odsiarczania węgla, praca doktorska WSP, Opole 1991.

4. Farbiszewska T., Cwalina B., Nowak A.: Izolowanie bakterii siarkowych z wód gruntowych i nadkładu Okręgu Turoszowskiego, Rudy Metale, 33, 11, 1988, 422-424.

5. Farbiszewska T., Farbiszewska-Bajer J: Bioekstrakcja siarki z węgla brunatnego: wpływ pH płynu ługującego, Fizykochemiczne Problemy Mineralurgii, 25, 1992, $77-81$

6. Gawdzik A., Farbiszewska-Bajer J.: Zastosowanie metody bakteryjnego hugowania do wstępnego odsiarczania węgla, Przemysł Chemiczny, 1990, 5, 1 214-216.

7. Karavaiko G.I., Kuznecov S.J. Golomzik A.I.: Rol mikroorganizmov w vyshhelachivanii metalov iz rud, Izdatelstvo Nauka, Moskwa 1972.

8. Karavaiko G.I.: Microbiological Processes for the Leaching of Metals from Ores, Torma A.E. (eds): UNEP, Moscow 1985

9. Kargi F. w: Mizrahi A., van Wezel A.L., (eds): Advances in Biotechnological Processes 3. Alan R. Liss, Inc., New York 1984, 241-272.

10.Lundgren D.G., Malouf E.E., w: Mizrahi A., van Wezel A.L., (eds) Advances in Biotechnological Processes 1. Alan R. Liss, Inc., New York 1983, 223-249.

Recenzent: Mgr inż. Ewa Kisielowska

Wplynęlo do Redakcji 27.09. 1996 r. 


\section{Streszczenie}

Podczas doświadczeń nad bioekstrakcją siarki siarczkowej z węgla brunatnego w skali laboratoryjnej zbadano wpływ temperatury, kwasowości i składu płynu ługującego, rozdrobnienia węgla oraz rodzaju i kompozycji użytych szczepów bakteryjnych na przebieg procesu. Wyniki tych prac potwierdziły możliwość prowadzenia procesu bioekstrakcji siarki siarczkowej z węgla brunatnego przy współudziale bakterii rodzaju Thiobacillus Przeprowadzono próbę bakteryjnego odsiarczania węgla brunatnego zawierającego $0,45 \%$ siarki całkowitej, w dużej skali laboratoryjnej. Proces prowadzono w reaktorze kamionkowym. Ługowaniu poddano $15 \mathrm{~kg}$ wegla brunatnego, o uziarnieniu około $30 \mathrm{~mm}$. Stosowanym płynem ługującym była woda destylowana zakwaszona kwasem siarkowym do $\mathrm{pH}$ 1,5 i zaszczepiona hodowlą autochtonicznych bakterii Thiobacillus ferrooxidans. Stosunek fazy stałej do ciekłej wynosił 2:3. Proces prowadzono w temperaturze pokojowej przez $40 \mathrm{dni}$. Ilość usuwanej siarki z badanego węgla oceniano, kontrolując wzrost zawartości jonów żelaza i jonów siarczanowych w płynie ługującym. Uzyskano $78 \%$ spadek zawartości siarki całkowitej w badanym węglu brunatnym. 